\section{MARCH 2011}

Interventional Cardiology 2011:

26th Annual International

Symposium

Interventional Cardiology 2011: 26th Annual International Symposium will be held March 13-18, 2011, at the Silvertree Hotel, Snowmass Village, Colorado. For information, contact: Promedica International CME (E-mail: rlaw@promedicacem.com; Web site: www.promedica.com).

\section{Society for Cardiothoracic Surgery in Great Britain and Ireland}

The 2011 Annual Meeting and Cardiothoracic Forum Excel will be held March 20-22, 2010, in London, United Kingdom. Further details and abstract submission are online at www.scts.org from September 1, 2010 (closing date is midnight November 5, 2010). For information, contact:sctsadmin@scts.org

\footnotetext{
$\overline{\text { Announcements }}$ of major meetings and other significant activities must be received at least 8 weeks before the desired month of publication. Information will be limited to title of meeting, date, place, and an address to obtain further information. Send announcements to Ryan Walther, Managing Editor, The Journal of Thoracic and Cardiovascular Surgery, 900 Cummings Center, Suite 221-U, Beverly, MA 01915 (E-mail: rwalther@prri.com).
}

The Advanced Revascularization

Techniques and Technology

Program

The Advanced Revascularization Techniques and Technology Program sponsored by The Heart Institute at Staten Island University Hospital will be held March 24, 2011, at the Regina M. McGinn Memorial Education Center, Staten Island University Hospital: The Heart Institute Staten Island, New York. For information, contact: John P. Demoleas (telephone: 718-226-6462; E-mail: jdemoleas@ siuh.edu) or Richard A. Clarke (telephone: 212-0545-7435; E-mail: RClarke@theHeartInstituteNY.com).

The Houston Aortic Symposium: Frontiers in Cardiovascular Disease

The Houston Aortic Symposium: Frontiers in Cardiovascular Disease will be held March 24-26, 2011, at the Westin Oaks Hotel, Houston, Texas. For information, contact: Promedica International CME (E-mail: Jtercheck@ promedicacem.com; Web site: www. promedica.com).

\section{APRIL 2011}

\section{0th Annual Mayo Clinic} Urogynecology and Disorders of the Female Pelvic Floor

The 20th Annual Mayo Clinic Urogynecology and Disorders of the Female Pelvic Floor will be held April
28-30, 2011, at the Fairmont Scottsdale Princess, Scottsdale, Arizona. For information, contact: Barbara LeSuer, Mayo School of Continuous Professional Development, Mayo Clinic, 13400 E Shea Blvd, Scottsdale, AZ 85259 (telephone: 480-301-4580).

\section{MAY 2011}

ACTS 2011: Advanced Cardiac

Techniques in Surgery: The

Eighth in the Series

ACTS 2011: Advanced Cardiac Techniques in Surgery: The Eighth in the Series will be held May 4-5, 2011, at the Equitable Center \& the Sheridan New York Hotel, New York, New York. For information, contact: Promedica International CME (E-mail: Jtercheck@promedicacem.com; Web site: www.promedica.com).

\section{JUNE 2011}

\section{The Society for Heart Valve \\ Disease}

The Society is pleased to announce that the 6th Biennial meeting of the Society will be held on June 25-28, 2011, in Barcelona. The meeting will again be a joint meeting with the Heart Valve Society of America. Please submit your abstract at: www.shvd.org. DEADLINE: 23:59 PM EST on Monday, February 7, 2011. For additional details, please visit: www.shvd.org 